\title{
Mobile application supported urban-township e-grocery distribution
}

\author{
Marcia Mkansi \\ Department of Operations Management, \\ University of South Africa, Pretoria, South Africa \\ Sander de Leeuw \\ Department of Supply Chain Analytics, \\ VU University Amsterdam, Amsterdam, The Netherlands and \\ Nottingham Business School, Nottingham Trent University, Nottingham, UK, and \\ Olatoye Amosun \\ Consumatech, Pretoria, South Africa
}

\begin{abstract}
Purpose - The purpose of this paper is to present a mobile application supported townshipand urban e-grocery distribution models that uses a software application (app) to bridge the infrastructural barriers, costs and complexities associated with e-grocery delivery operations in rural township areas.

Design/methodology/approach - Using a qualitative multi-case approach and semi-structured interviews, the study explored distribution practices of eight national emerging e-grocery retail businesses to demonstrate how mobile applications can facilitate South African urban and township e-grocery delivery models.

Findings - The study reveals how the need to scale the use of new mobile application innovations fuels value-added services that power new e-grocery distribution models. Of interest is how the application aggregates demand rapidly, respond to demand within a short lead time and how e-grocers use competitors' stores as their fulfilment centres. The use of apps reveals a slow transformation of society towards an inclusive model that integrates different types of workers in an informal context.

Practical implications - The mobile application value-added service business model offers a new wave of scaling e-grocery retail to rural and township areas constrained by technological, economic and road infrastructure. The apps transcend e-grocery barriers and enables small businesses with limited resources to leverage e-grocery market opportunities that are unimaginable in townships and rural areas.

Originality/value - The innovative mobile platform-base model offers emerging contextual insight of a pull e-grocery distribution model that demonstrates the supply chain innovations for addressing under-resource and under-developed logistics infrastructure.
\end{abstract}

Keywords Mobile applications, E-grocery distribution models, Order management,

Urban and township delivery

Paper type Research paper

\section{Introduction}

E-grocery retail business models have been studied mostly in urban and city environments (Morganti et al., 2014; Durand and Gonzalez-Feliu, 2012; Gevaers et al, 2011; Murphy, 2007). The urban and city focus is due to the perception of complexities and cost associated with supply and distribution of e-groceries in such environments (Ishfaq et al., 2016; Aspray et al., 2013). However, findings from such studies prove difficult to be rolled out easily to townships and rural areas where road and internet infrastructure is still in its infancy (Foster and Briceno-Garmendia, 2010; Murphy, 2007).

Even in urban and city environments the challenges of efficient and effective distribution are abundant. In the context of costs of e-grocery retail, Ishfaq et al. (2016) found a network complexity cost in their study of the realignment of physical distribution channels in omni-channel retail. Yang et al. (2014) unveiled issues of additional expense for 
transportation in an attended home-delivery model. Gevaers et al. (2011) state that "not-at-home" deliveries of the last mile imply extra costs. Aspray et al. (2013) reiterate the high cost and complexity of fulfilment for groceries bought online. Asdemir et al. (2009) also emphasise the challenge of balancing utilisation of delivery capacity against time and profit margin in e-grocery retail. Recent studies by Larke et al. (2018) illustrate the complexity in achieving omni-channel retailing in even a mature market. To add to this, Goethals et al. (2012) point towards the additional task of order preparation, delivery activities and investment associated with e-grocery retail as key deterrents for many businesses. To this end, Agatz et al. (2011) introduce a time-slot pricing tool inspired by e-grocery operations. They conclude that high costs in transportation may be related to setting narrow delivery time slots and that there are clear economies of scale in increasing stops. These studies are typically inspired by or set in an urban or city business perspective. However, as Agatz et al. (2011) argue, a regional differentiation of services may lead to significant cost savings. All these studies point towards difficulties in managing e-commerce in grocery retail in urban and city settings and successfully rolling out such distribution models to township and rural areas may, therefore, be even more difficult to achieve.

This study is set in South Africa, where small e-grocery operators are infiltrating the urban, township and rural markets (see Appendix 1 for further details on the grocery retail market in South Africa). Tu et al. (2018) argue that it is pivotal to establish good e-commerce logistics in rural areas to fuel further growth, since studies in China have shown that rural e-commerce logistics may be a bottleneck in e-commerce development. In China, large retailers aim to seize the rural e-commerce market by building their own logistics network. Tu et al. (2018) indicate that Taobao Mall and Tmall established 1,000 county-level service stations and 100,000 village service sites with an investment of $\$ 1.5 \mathrm{bn}$. However, the authors also argue that in China companies still have a long way to go before rural e-commerce logistics can be run effectively and efficiently. This prompted the quest of what innovations are needed in the supply chain to address limited resources and under-developed logistics infrastructure.

A comparison of studies on South Africa's top three e-grocery retailers' practices (Weber and Badenhorst-Weiss, 2018) against those of the developed world and other developing countries (Hubner et al., 2016; Waitz et al., 2018) reveals very few differences in terms of the distribution models, but rather more variations of contexts underlying the e-grocery retail operations. For example, Weber and Badenhorst-Weiss (2018) reveal three picking options used by a leading e-grocery retailer in the urban areas of South Africa: in-store, centralised distribution centres (DCs) and central warehouse. Hubner et al.'s (2016) holistic strategic planning framework for last mile orders, observed from different published e-grocery studies in the European Union, also reiterates the same picking options. Mkansi et al. (2011) reinforce the same observations regarding the supply and distribution network models (piggyback, hybrid and DC models) used by leading grocery e-retailers in the UK, namely: Tesco, Waitrose, Asda and Ocado. Marchet et al.'s (2018) reiterates in-store as a business logistics model used by food retailers in Italy. The same distribution models are used by other top e-grocery retailers in the developed world such as Germany, France, China and the Netherlands (Mkansi et al., 2018; Lim et al., 2018), and the USA (Li et al., 2018; Waitz et al., 2018; Aspray et al., 2013). A limited context of e-grocery operation models in developing world countries such as India and Pakistan offer similar insights of distribution models use in urban contexts (Bharucha, 2017; Saleem et al., 2018).

All in all, the transition of findings set in urban developed world contexts to townships and rural dwellings is complicated as the latter are perceived to be constrained by lack of a proper digital infrastructure, accurate information and communication technologies, high cost of distribution, expensive data and unstructured road systems, all of which make it hard to deliver (Foster and Briceno-Garmendia, 2010; Murphy, 2007). The aim of the study is 
to explore how small and medium e-grocery businesses use innovations to bridge the supply chain challenge of limited resources and under-developed logistics infrastructure in urban, township and rural e-grocery distribution. In order to do so the extant literature is reviewed, and a multiple case-study approach is employed to gain a deeper insight into the urbantownship e-grocery distribution models. The study findings show how the use of mobile applications integrates different types of workers in an informal context. To facilitate order processing in townships and rural areas entrenched with issues typical of a context, unemployed youth are deployed to curb obstacles of technological challenged market segments. In addition, apps allow for overcoming issues typical of unstructured roads and street numbers through the use of GPS to capture locations for order delivery. In particular, it reveals a slow transformation of society towards a crowdsourcing-enabled model.

The following section presents a literature review of the urban, township and rural e-grocery context. After that, the third section reviews the research methodology and the fourth section presents results which are discussed in the fifth section. The sixth section concludes the paper.

\section{Urban, township and rural e-grocery contexts}

Scholars have long acknowledged the interrelationship between distribution network configurations on the one hand and, on the other, the physical geographical development of urban, township and rural dwellings (Osterle et al., 2015; Ploos Van Amstel, 2015; Blanco and Fransoo, 2013). Although emphasised differently, a common theme centres on urban, township and rural design parameters as crucial inputs for distribution and network configuration. For example, Osterle et al. (2015) acknowledge the importance of well-functioning urban distribution systems for distribution of goods to the stores and its economic contributions to the region. Ploos Van Amstel (2015) stresses how transport and technological infrastructure alters distribution models and logistical elements which may confer advantages for those businesses within such contexts. Hughes (2012) emphasises that infrastructural designs (i.e. urban, township and rural designs) and spatial organisation of transport and mediating technological infrastructures play a differential and direct role in enabling distribution of goods and services. Cant (2017) argues that access to infrastructure is a prerequisite for small businesses to thrive and highlights how the lack of infrastructure in the townships of South Africa hinders small businesses. Oduwole (2018) discussed that infrastructural development goes hand-in-hand with entrepreneurship development necessary for accommodating townships peculiarities. As such, the fact that urban, townships and rural areas take different forms of designs (Blanco and Fransoo, 2013) highlights spatial variations that need to be considered in the evaluation of e-grocery distributions models. Such spatial variations and its interrelationships with e-grocery retailers from different contexts, especially those with limited resources and underdeveloped logistics infrastructure, remains silent in the literature. Yet, understanding spatial differences is crucial in determining how e-grocery distribution models manifest across contexts, specifically the interactions of e-grocery retailers with such environments. Below, an overview of the peculiarities of urban, township and rural contexts is provided and thereafter of the role of mobile innovation, which sets the conditions under which e-grocery models are configured. The South African context of grocery retail in which this research is set is discussed in Appendix 1.

\section{Urban e-grocery context}

Although distribution networks are, on average, more advanced in urban areas than in township and rural dwellings, distribution networks in developing countries cannot be presumed to be on par with those of developed worlds (Blanco and Fransoo, 2013; Zaide, 2012; Lawrence and Tar, 2010). For example, in developed countries information technology 
(i.e. mobile broadband, data and cloud computing) and industrial convergence (i.e. electric grids, transport networks and household appliances), which is necessary for sustainable e-grocery operations, is more advanced than in developing countries (Blanco and Fransoo, 2013). Moreover, the income disparity is minimal in developed countries as opposed to urban areas of developing countries (Blanco and Fransoo, 2013). Such disparities are crucial factors that contribute to the success of e-grocery operation.

In South Africa, urban areas struggle with reliable electricity supply and operate under intermittent load shedding, an interruption of electricity supply to businesses and communities aimed at balancing demand, to prevent the collapse of the power system (plant) which is not present in developed worlds (Baptista, 2018). In fact, load shedding hurts the economy as well as the supply chains of many businesses (England, 2015; Bisseker, 2015). In terms of e-grocery, this extends well beyond unreliable traffic lights that affect on-time delivery and lead to increased road congestion, but also encompass, for example, limited abilities for cold storage of chilled and frozen products and disruptions in processing of payments. Whilst the technological and load shedding issues cannot be assumed to be the single factor differentiating urban distribution in the developed world vs that in South Africa, they do illustrate the importance of understanding contextual e-grocery distribution issues. Urban contexts need a different approach in the supply chain but South Africa has interesting aspects by itself, such as the unique spatial legacy of urban, township and rural contexts from the apartheid era, which makes visible the interface between economical structures and spatial inequality (Philip, 2010).

\section{Township and rural e-grocery context}

Townships and rural areas in many developing countries are known to have homogenous characteristics such as income disparities (Blanco and Fransoo, 2013), immature logistics infrastructure, low credit card penetration and poor telecommunications infrastructure (Zaide, 2012; Lawrence and Tar, 2010). Yet, in order to successfully offer e-grocery operations, the infrastructure needs to be embedded within the geographical and economic structures (Murphy, 2007). In fact, the top ten global leading e-grocery retailers thrive due to their advanced telecommunication systems, high number of stores and DCs capabilities dispersed across different markets, and mature logistics systems which are considered to be some of the veins that sustains e-grocery operations (Polacco and Backes, 2018; Lu and Reardon, 2018; Walmart, 2018). Yet, small e-grocery retailers in the townships and rural areas of South Africa contend without the infrastructural and resource muscles observed in the practice of top grocery retailers.

In South Africa, unlike in many other developing countries, townships have inherited designs which had no economic logic and prohibited business activities from the apartheid era. In fact, the majority are still dependent on cities for retail facilities (Thulo, 2015; Philip, 2010). The South African townships are highly characterised by a fragmented logistics network, poverty and a complex spectrum of unstructured street numbers (Shackleton et al., 2018; Schoeman, 2018). Security and crime are rife in townships and the majority of the population relies heavily on cash which places drivers and distributors at high risk of robbery (Agwa-Ejon and Mbohwa, 2015; Blanco and Fransoo, 2013). The inherent apartheid legacy has left most of the population with high economic and income disparities (Oduwole, 2018; Cant, 2017; Thulo, 2015). As such, townships and rural areas consist of poor and rich neighbourhoods (Cant, 2017; Philip, 2010). For example, in Soweto a mixture of rising middle-class and low-income class is observed (Alexander, et al., 2013) whilst Alexandra boosts a huge informal settlement that co-exists next to the most expensive square in Africa, Sandton (Makhubu, 2016). Put simply, the majority of the people in townships and rural areas struggle to make ends meet, rely on social grants (Oduwole, 2018) and data or internet costs are quite high (Calandro et al., 2014; ITU, 2014) making connection to the internet a 
luxury outside their bounds. Many townships and rural areas including informal settlements operate without electricity connection (Baptista, 2018), structured phone lines, and have limited water supply, and where available, poor connection and/or supply persists (Hosu et al., 2018). Furthermore, the economic wealth of South Africa is highly centralised to big corporates in cities and urban areas, and tend to exclude participation by small businesses (Philip, 2010). As a consequence, most of the top five grocery e-retailers rarely have a presence in rural areas, and they offer limited presence in townships.

A well-functioning economic and physical infrastructure are necessary to support egrocery activities, however, these are often lacking in townships and rural areas. The complexities of townships and rural structures in South Africa led Oduwole (2018) to suggest that strategic and structural policy interventions may be the best answer towards bridging the inherited economical gap. However, it is the lack of presence in rural areas and the limited offerings in townships and rural areas of the large retailers that have fuelled mobile innovators to seize the gap in the market. Small grocery e-retailers may play a role in bridging the physical infrastructure gap (and potentially also the economic gap) to consumers by offering a mobile technological intervention that contributes towards poverty alleviation, redressing of inequality and simulate employment.

\section{The role of mobile applications in configuring supply chains}

Mobile application technologies have received a great deal of attention in supply chain management, especially in business applications and consumer applications. From a business application perspective, Eng (2006) focussed on mobile applications in enabling location-based service through the use of global positioning system and enabling remote accessibility of company's database through the combination of radio frequency identifications and short message service database. Shih and Wang (2016) applied a wireless sensor network for cold chain systems. Pan et al. (2013) presents a model for the adoption of mobile supply chain management. Consumer applications studies present, for example, mobile apps for supporting customer integration in the designs of products and manufacturing network (Mourtzis et al., 2016). The increasing application of mobile applications in the supply chain has further advanced wireless food ordering system in restaurants (Mishra et al., 2015; Khairunnisa et al., 2009). Nguyen et al. (2018) acknowledge the role of mobile devices in creating order fulfilment opportunities for customers and retailers.

Another wave of research focussed on the barriers to mobile application diffusion in different segments of the supply chain (Alalwan et al., 2016; Liu et al., 2015; Thi et al., 2016; Lee and Han, 2015). The major concern raised by the latter scholars centres on the initial and operating costs such as data costs necessary for accelerating diffusion (Lee and Han, 2015; Thi et al., 2016). Alalwan et al. (2016) and Liu et al. (2015) point towards data privacy as a major limitation associated with mobile banking and mobile coupon application diffusion, respectively.

Several more studies report on the specific use of mobile tools in the e-grocery supply chain (Cagliano et al., 2017, 2015). Cagliano et al. (2017) developed a system dynamics simulation model to capture and understand the cause and effects of time-dependant relationships enabled by mobile tools. Cagliano et al. (2015) identified reliability and efficiency of the service as crucial drivers for the diffusion of smartphone adoption in the e-grocery supply chain. The findings from the latter scholars offer great insight on how the adoption of mobile tools can enhance e-grocery supply chains. However, not much, if any, is available towards understanding how mobile applications are used to address limited resources and under-developed logistics infrastructures in the distribution of e-groceries, especially in models that extends urban to townships and rural areas.

Given the fact that distribution networks in developing countries are not on par with those of developed worlds, the challenges in e-grocery retail are significant. This is often 
exacerbated by the lack of a well-functioning economic and physical infrastructure in townships and rural areas. Given the fact that large grocery e-retailers rarely have a presence in rural areas, or in townships, other solutions are needed that can be adopted in situations with limited resources and under-developed infrastructures. Mobile tools may provide an answer to this and the case-study discussed below will discuss how.

\section{Methodology}

A qualitative multiple case-study approach is used in gaining insight into mobile application supported urban-township e-grocery distribution, especially in consideration of the complexity of logistics elements, cost and thin profit-margin challenges that are observed in matured e-grocery markets and urban/city settings. The study received access to 8 case studies from the 13-known pertaining to the emerging population of national urban to township e-grocery operators in South Africa. The suitability of qualitative research in producing rich and in-depth description of the phenomenon is discussed by previous studies (Yin, 2015; Clark and Creswell, 2015). An interview guide was developed based on the elements of logistics with consideration paid to the context of e-grocery operations outlined by Mkansi et al. (2018). An exploration of the eight e-retailers in terms of their logistics elements provided an opportunity to identify diverse and common practices existing between township and urban e-grocery players, in particular their effect on the cost of operation (Ishfaq et al., 2016; Aspray et al., 2013; Asdemir et al., 2009) and profit strategies recognised as a major barrier to entry. At the same time, the method provided an insight into the South African township context. Appendix 2 provides more detail on the sampling strategy.

\section{Findings}

\section{Case description}

Of the eight-emerging e-grocery operators, four of them are not traditional grocery retailers characterised by stock levels and brick infrastructure such as stores. Two have two DCs where they store and break bulk of the aggregated orders whilst the others only have one DC (see Table I for summaries). Put simply, they manage to use technology to bypass the costs and ownership of some of the logistics elements considered critical in the sustainability and success of leading global e-grocery retailers such as stores and DCs used

\begin{tabular}{|c|c|c|c|c|}
\hline No. & $\begin{array}{l}\text { Logistics } \\
\text { processes }\end{array}$ & $\begin{array}{l}\text { Retailer configured } \\
\text { model (Companies: B, C, } \\
\text { E and G) }\end{array}$ & $\begin{array}{l}\text { Wholesaler configured model } \\
\text { (Companies: D, F and H) }\end{array}$ & $\begin{array}{l}\text { Brand configured model } \\
\text { (Company A) }\end{array}$ \\
\hline 1. & Order storage & $\begin{array}{l}\text { Competitor's store, i.e. } \\
\text { Woolworths, Pick n Pay, } \\
\text { Checkers }\end{array}$ & $\begin{array}{l}\text { Distribution centres, kiosks, and } \\
\text { bigger spaza shops customers }\end{array}$ & $\begin{array}{l}\text { Distribution centres, } \\
\text { and township household } \\
\text { garages }\end{array}$ \\
\hline 2. & Order delivery & $\begin{array}{l}\text { Independent drivers, i.e. } \\
\text { Uber, Taxify, car } \\
\text { owners }\end{array}$ & $\begin{array}{l}\text { Independent drivers, i.e. } \\
\text { townships people with cars, and } \\
\text { own drivers }\end{array}$ & $\begin{array}{l}\text { Distribution centres, } \\
\text { kiosks and bigger spaza } \\
\text { shops customers' }\end{array}$ \\
\hline 3. & $\begin{array}{l}\text { Order picking } \\
\text { and assembly }\end{array}$ & $\begin{array}{l}\text { Independent personal } \\
\text { shoppers, i.e. } \\
\text { unemployed youth, } \\
\text { students }\end{array}$ & $\begin{array}{l}\text { Independent personal shoppers, } \\
\text { i.e. unemployed youth, students }\end{array}$ & $\begin{array}{l}\text { Independent personal } \\
\text { shoppers, i.e. } \\
\text { unemployed youth, } \\
\text { students }\end{array}$ \\
\hline 4. & Order stock & $\begin{array}{l}\text { Competitors stock } \\
\text { ambient, chilled, frozen } \\
\text { and fresh produce }\end{array}$ & $\begin{array}{l}\text { Competitors stock ambient, and } \\
\text { fresh produce that can be stored } \\
\text { as ambient, i.e. potatoes }\end{array}$ & $\begin{array}{l}\text { Competitors stock } \\
\text { ambient }\end{array}$ \\
\hline 5. & $\begin{array}{l}\text { Order entry } \\
\text { and processing }\end{array}$ & $\begin{array}{l}\text { Mobile app, WhatsApp, } \\
\text { E-mails }\end{array}$ & E-grocery mobile app & E-grocery mobile app \\
\hline
\end{tabular}

Table I.

Summary of case findings 
by leading players, i.e. Tesco, Walmart, Carrefour Group and CVS (Mkansi et al., 2018; Pan et al., 2017). When asked about their rationale for the e-grocery app and service, participants offered different motives but commonly emphasised the need for convenience, scalability of their mobile applications, reach to untapped rural and township markets by linking formal and informal markets and the reduction of high unemployment opportunities. Within the rationale for convenience, the participants highlight two unique propositions different from existing large e-grocery retailers. On the one hand, they highlight the customers' convenience to shop from multiple grocery retailers within a single platform rather than being limited to a single retailers' platform, and/or having multiple or separate transactions with different retailers. The other convenience is in terms of employment, which creates opportunities for independent shoppers and independent drivers to serve multiple e-grocery retailers at their convenience whilst lifting a heavy weight that comes with permanent employment for the small grocery players. Below we describe the three distribution models. Appendix 3 summarises interview quotes that further illustrate each of the models.

\section{Mobile application configured e-grocery distribution models}

Although described differently, the eight e-grocery operators' distribution models are essentially categorised into three: mobile application retailer configured model, mobile application wholesale configured model and mobile application brand manufacture configured model (see Figures 1-3).

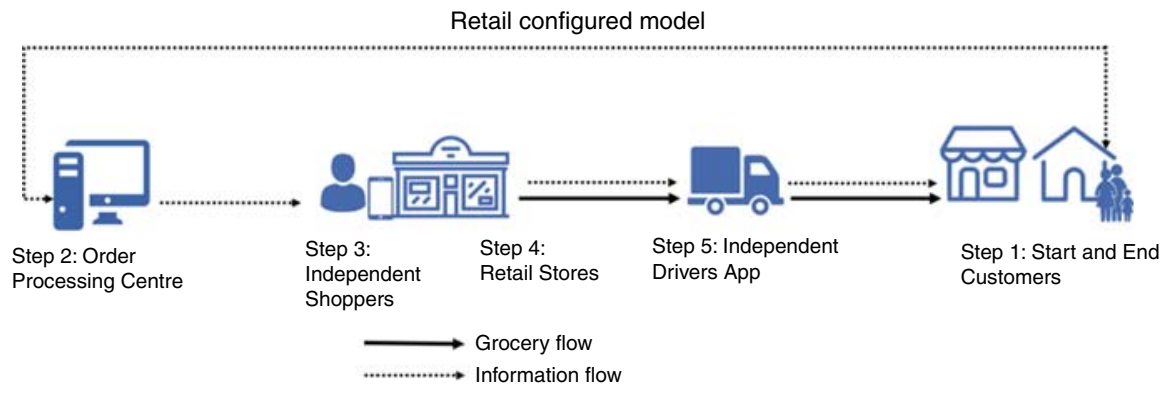

\section{application}

Mobile

\section{西}




\section{IJPDLM}

Figure 3.

Mobile application

brand/FMCG

configured model

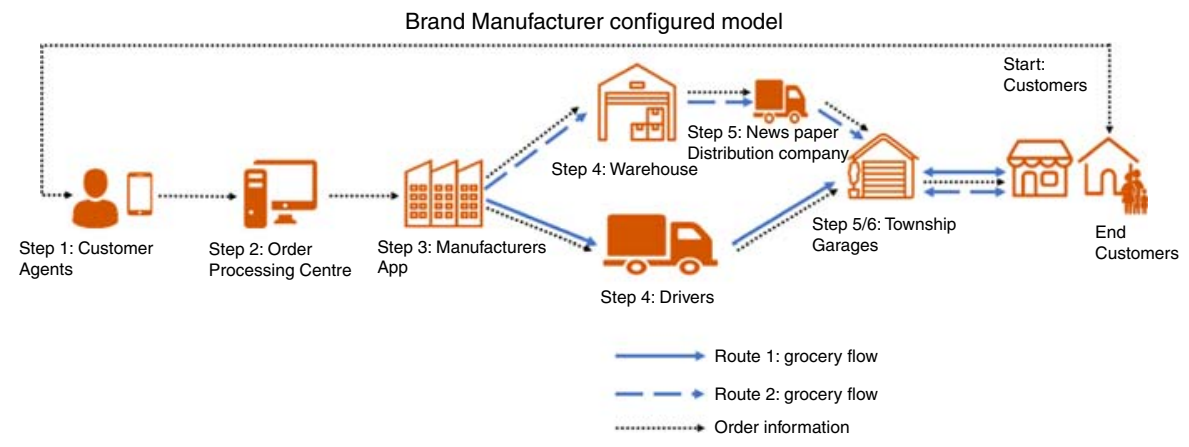

Mobile application retailer configured model

The mobile application retailer configured model (Figure 1) is the most popular model and used by four small grocery e-retailers. The mobile app streams live e-grocery orders through the app to managers based in a centralised office. The managers extract orders, process and filter them on the basis of the mall's proximity to the customers' home. The filtered orders are re-rooted to independent shoppers waiting in malls closest to customers' location to start picking. The independent shoppers pick from the customers' preferred grocery retailers such as Pick n Pay, Woolworths, Food Lovers Market or Shoprite and Checkers. As the independent shopper picks and scan orders to the trolley, a tracking feature alerts independent driver of minutes to, or time of, completion and predicts time for groceries to be collected from shoppers who meets the driver at the car park in time for delivery to customers' homes. At the point of delivery, the customers show the independent driver a code to approve and confirm the accuracy of orders. Put differently, the small e-grocery players indicated they do not have stores or grocery stock but utilise competitors' bricks and mortar grocery stores and stock placed in malls and other geographical areas nearest to their market segment as fulfilment hubs (see Appendix 3 for quotes).

The orders come from middle-class urban dwellers, office parks, students, single mothers, mothers with small babies and townships households. The interesting perspective of mothers participating in online grocery retail is that e-grocery shopping provides much more convenience for women with toddlers. As one executive said:

The insight that we received from mothers is that they do not want to go with their kids to do grocery shopping. So it is better to use our platform to do groceries and we can just deliver.

Within this model, formal and informal partnership exists between the small e-grocery operators and the large grocery retailers. The formal partnership is established under a 5-10 per cent profit share model based on total cost of sales generated by the small grocery e-retailer to the large retailer store, opined as:

We have partnerships with Woolworths, Food Lovers Market and we are in the process of finalising the agreement with Pick n' Pay as well.... Food Lovers give us a 5-10\% commission based on agreed sale volumes.

Amongst those small grocery e-retailers without formal partnership, some appears to have made themselves known to the store managers of the grocery retailers, in which they pick from. However, there is no profit share model on the basis of sales figures generated by the small grocery e-retailers:

We did very much close contact with store managers at Pick and Pay, Woollies and so on. So, before we even started operating there, we introduced ourselves, we got to know the whole management team and how the store works. 
For those small grocery e-retailers that bypassed formal partnership and formal introduction, there have been no channel conflicts. Rather, liaison with fast moving consumer goods (FMCG) manufacturers such as Tiger Brands is reported. The FMCG appears to have great interest in the existence of the small grocery retailers as they have become the veins through which unavailability of brands products is communicated. The FMCG's brand is in competition with retailers' own brands hence the valued intelligence. The insight on unavailability of brand products appears to have mutual benefits in that whilst FMCG collects information small grocery e-retailers are increasing chances of order accuracy for their customers. Further, small grocery e-retailers earn an affiliated advertising fee for products displayed by FMCGs on their app. The advertising fee complement the 5 per cent service fee and added delivery fee reported by all grocery e-retailers as: "we charge a service fee of about $5 \%$ and delivery fees and use the money to pay independent contractors". The rationale for lack of partnership and formal introduction appears to be perceived fears of prolonged meeting with grocery retailers' management team and delays to the market (see Appendix 3 for quotes).

\section{Mobile application wholesale configured model}

The second popular distribution model is the mobile application wholesale configured model which is utilised by three small grocery e-retailers. Orders are generated by foot agents from a host of B2B and B2C customers. The app aggregates the demand from the foot agent's mobile interface which is used by the executives to negotiate economies of scale. The bulk purchase is collected from wholesalers by independent drivers. The drivers break the bulk in vans and redistribute to different townships and rural areas. For those small grocery e-retailers with a single DC, if the bulk is too big, drivers deliver to the DC for breaking bulk purposes before redistributing to customers. Where a customer is not available to receive the order, the driver returns it to the kiosk in a specific township location, giving customers an option to collect at their convenience (see Figure 2 and Appendix 3 for quotes).

Orders are generated from household customers (B2C) and business customers (B2B). The B2B customer's segments include spaza shops, funeral societies, bakeries, chisanyama restaurants, khota bread traders (sipahlo), crèches, office parks and caterers who used products as inputs to their business. The B2C models are house individuals, pensioners, students, mothers and social grant holders for consumption purposes. The B2B groups are key in aggregating weekly demand in the downstream chain as opposed to low order volumes in the $\mathrm{B} 2 \mathrm{C}$ segment. Whilst the majority of $\mathrm{B} 2 \mathrm{~B}$ use the grocery as inputs into their businesses, some of the B2B buy groceries for staff consumption. Together the two market segments assist the e-grocery operators in capturing data, monitoring repeat orders and understanding their loyal and new customers (see Appendix 3 B2B for quote).

The e-grocery operators use customer segments as complementary to the $\mathrm{B} 2 \mathrm{~B}$ whose customers with high weekly order patterns in townships. The insight from the e-grocery retailers is that the economic status of the $\mathrm{B} 2 \mathrm{C}$ township and rural groups means they can only buy in volumes on a fortnightly and monthly basis. The rest of the time is mainly top-up grocery purchases (see Appendix 3 for B2C quote).

Similar to the mobile application retailer configured model, the fulfilment centres of the mobile app wholesale configured e-grocery operators are mainly their competitors (traditional grocery retailers stores such as Pick n Pay, Woolworths, Shoprite Checkers etc., fresh produce markets and wholesalers/discounters like Makro) situated in the malls or geographical areas nearest to their market base segments. Of particular interest was how the mobile application wholesale configured model yield profit in an industry characterised by thin profit margins (Asdemir et al., 2009). The strategies outlined by the e-grocery retail include mark up from economies of scale strategy induced by aggregating demand at the downstream chain (see Appendix 3 for economies of scale quote). 


\section{Mobile application brand/FMCG configured model}

The mobile application configured brand manufacturer model (Figure 3) represents a unique and niche approach only utilised by one e-grocery operator. The model generates demand of specific brands in the base of the pyramid (rural and township markets B2B and B2C markets). Foot agents sign up spazas and customers for specific brands. The mobile app pulls demand data from various townships agents' mobile repositories which are shared with participating brand manufacturers. Packaged order information is communicated through the manufacturer-spaza application/driver mobile application interface, who collects and delivers bulk orders to either a central DC, independent newspaper distributors or household garages in townships. The volume and location of customers dictates the direction of the delivery. The DC and partnering garage household owners break bulk which is picked by independent drivers in townships straight to spazas and other customers.

The executives behind this model are of an opinion that, in store, brands' visibility is impaired by competition. The executives' view corroborates an earlier insight into FMCGs interest in small e-grocery retailers' communication of unavailable products. Big Data residing with the mobile application brand models is found to be the oil that fuels the FMCGs interest and helps them to gather intelligence necessary for analysing the value chain. The executive opined that: "We also have the technology and the data behind us which offer a much better information gathering system than the traditional routine market”. Against such a backdrop, the brand manufacturer configured model offers FMCGs and brand manufacturers a direct link to the base of the pyramid in particular, informal markets where brands have minimal visibility and awareness. The link between formal and informal market bring with it low cost per unit due to the removal of the middle man (i.e. wholesalers and retailers) in the upstream chain. The low cost is what gives the brand model a competitive advantage against other online and offline grocery stores and wholesalers (see Appendix 3 for quote).

Of particular interest is the model's profit strategy; unlike the other grocery retailers where margins are generated from the downstream chain, the upstream chain sustains the model and carries much of the margins' weight. The rationale put forward is that brand manufacturers pay for the greater penetration of their products and awareness of their brand directly to customers. The major emphasis is on driving the cost down upstream, which influences competitive demand from the downstream chain (see Appendix 3 for quote).

\section{Logistics process management in urban-township e-grocery distribution}

The management of logistics elements is considered to be highly complex and to hold the key to successful retailing (Rushton et al., 2014; Reiner et al., 2013). For this reason, there is a need to explore how the emerging grocery operators manage these elements (see Appendix 3 for quotes).

\section{Order entry and processing (communication)}

Apart from the mobile application configured models, social media applications such as Facebook and WhatsApp are some of the order processing methods used. Companies A, B, $\mathrm{E}, \mathrm{F}$ and $\mathrm{H}$ are teams of mobile application innovators who pushed their technology (mobile application) to the market through an e-grocery business model. Company D uses a website and is part of a wholesale company that decided to offer e-groceries through the website. Companies' $\mathrm{C}$ and $\mathrm{G}$ saw WhatsApp and e-mails as complimentary platforms for management of order entry necessary to complement the website. The chief executive officers (CEOs) started experimenting with order processing on social media platforms and added a complimentary website with the growth of the business. "We used WhatsApp and e-mails for proof of concept and to manage our orders. With that concept given we 
built our website with information on how customers order". For the township and rural market, the e-grocery players appear to have mastered the needs of their society such as convenience, time saving, demand patterns, distance to retail facilities and unemployment and their complementary challenges such as digital illiteracy, cost of data, and ailing technological and road infrastructure. The needs and challenges are factored in the design of their mobile application technologies and evident in their clear strategy of how the different levels of e-grocery logistic elements connects and interact within the physical fabric of urban, townships and rural areas. As such, the companies deploy young people to collect and process orders on behalf of the technological challenged townships and rural market.

\section{Order stock (inventory)}

Only two of the e-grocery operators offer all categories of grocery stock including chilled and frozen. "We do everything from veggies to meat; meat, frozen goods, we do everything including alcohol and beverages. So we do almost the whole grocery line; we don't limit our customers". The majority are only offering ambient products due to the legal requirements and the cold chain management associated with e-groceries. Three companies limit their fresh produce offering to those that can be stored ambient.

\section{Order storage (storage)}

There are seven storage approaches used for chilled and frozen products by the e-grocery operators: cooler bags, grocery retailers' partners refrigerated storage, kiosk, time frame strategy, partnership with spaza customers with high volume orders and courier partner's DC. Five e-grocery operators have no DCs, stores and refrigerated storage. Amongst those that provide chilled and frozen products, one uses cooler bags from the stores to the customers' house. However, in transit of groceries from retailers to customers, some grocery operators use cooler packs for chilled and frozen products. The small e-grocery retailer that has a formal partnership with the competitor appears to benefit from safety standards guidance from Woolworths and use of their fridges to keep the cooler bags at a desired temperature. However, one of the e-grocery operators who supplies both urban and townships in use of the mobile application wholesale configured model has a network of kiosks for breaking bulk and returns purposes.

The three e-grocery operators using the wholesale distribution model have different DC models. The one in partnership with a courier company has one DC and uses their courier delivery partner's DC. The verbatim statement of the executive is:

We have one distribution centre. When the orders are prepared the couriers pick it up and they take it to their distribution centre and they distribute from there. So basically, we use outbound logistics.

The one in partnership with bigger townships customers has two DCs; one in Soweto and Alexandra, respectively. For market penetration, the township operator uses the storage of their biggest company as a strategic storage for breaking bulk and penetration to the market. In Durban, one company entered into partnership with township household owners offering their garage as a storage place for dropping stock and breaking bulk, thus creating micro-employment opportunities.

An interesting insight was that one e-grocery operator plans time frames to manage the in-transit storage of chilled and frozen products (rather than cooler bags and boxes):

We ask the customer when to deliver i.e. if the customer wants his/her order to be delivered at 3pm, we usually buy the groceries in the supermarkets at the shopping mall that is nearest to his/her house nearest to the desired time. That is how we make sure that the ice cream gets there while it is still intact. 


\section{Order picking and assembly (unitisation and packaging)}

The majority of the companies (seven) utilise the service of independent personal shopper contractors; the other two utilise drivers and their own in-house personal shoppers or do it themselves. The fact that unemployment is high in South Africa and big retailers are far from townships and rural areas give small e-grocery operators certain advantages which townships and rural areas reinforce. Put simply, e-grocery operators' benefit from high unemployment, spatial inequality, lack of digital infrastructure and the existence of businesses with high percentages of technological challenges (see Table II and quotations below). The emphasis by one of the executives is:

We try to get women and unemployed youth, that is always our key. Then we position ourselves as social entrepreneurs. We do look at getting young guys in and, if not young guys, women.

The small businesses that handle most of their operations outsource on an ad hoc basis depending mainly on volume.

\section{Order delivery (transportation)}

The majority of the companies (five) use mobile applications to mobilise the service of independent driver contractors including taxi associations, Uber, Taxify and Delivaroo drivers: "We have drivers who are independent contractors including, Uber, and Taxify". The other two grocery operators use their own personal bakkies (also known as small pick-up trucks), scooters and bicycles: "We are using medium and small size bakkies such as Bantam size versus a 3ton bakkie". According to the executive, order volumes influence the mode and size of transport to use.

The two e-grocery operators in partnership with a courier company and an independent newspaper network benefit from the partner's logistics network assets and capabilities, respectively. The courier delivers throughout South Africa which gives the small e-grocery retailer a greater penetration to the market.

The e-grocery retailer in partnership with taxi association demonstrates a wave of transport alliance that is usually observed in airlines. The difference in this case is that the alliance is between a passenger vehicle and an e-grocery provider. The e-grocery retailers have realised

\section{Table II.}

Order picking and assembly

\begin{tabular}{|c|c|c|c|c|c|c|c|c|}
\hline \multirow{2}{*}{$\begin{array}{l}\text { Order } \\
\text { picking and } \\
\text { assembly } \\
\text { aspect }\end{array}$} & \multicolumn{8}{|c|}{ E-grocery operators } \\
\hline & $\begin{array}{c}\text { Company } \\
\text { A }\end{array}$ & $\begin{array}{c}\text { Company } \\
\text { B }\end{array}$ & Company & $\begin{array}{c}\text { Company } \\
\text { D }\end{array}$ & $\underset{\mathrm{E}}{\text { Company }}$ & $\begin{array}{c}\text { Company } \\
\text { F }\end{array}$ & $\underset{G}{\text { Company }}$ & $\begin{array}{c}\text { Company } \\
\mathrm{H}\end{array}$ \\
\hline $\begin{array}{l}\text { Own } \\
\text { Independent } \\
\text { personal } \\
\text { shopper } \\
\text { contractors }\end{array}$ & & * & & & * & & & \\
\hline $\begin{array}{l}\text { Unemployed } \\
\text { youth }\end{array}$ & & $*$ & $*$ & & & & & $*$ \\
\hline Drivers & & & & * & & & & $*$ \\
\hline $\begin{array}{l}\text { CEOs DIY or } \\
\text { outsource } \\
\text { with bigger } \\
\text { volumes }\end{array}$ & $*$ & & $*$ & & & & $*$ & \\
\hline $\begin{array}{l}\text { Wholesale } \\
\text { picks build } \\
\text { orders }\end{array}$ & & & * & & & $*$ & $*$ & \\
\hline
\end{tabular}


that taxis are rarely busy during off-peak hours and offered them a profit-sharing proposal that is beneficial for both parties. One small e-grocery retailer argued that taxi drivers provide some sense of security from possible hijacks because nobody will hijack people.

In the absence of structured road and house numbers, which are critical for on time and right place delivery, mobile technology and geographical information systems become the saving grace. An interesting insight was how two of the e-grocery operators use the mobile app to capture coordinates to deal with the issue of unstructured streets and roads in townships for the purpose of deliveries. When the personal shopper takes an order in the township, s/he captures the coordinates which is later used by the driver to ensure deliveries (Table III).

Three of the e-grocery operators in urban areas and townships offer deliveries for free: "We are absorbing the cost of the courier charge but we will be adding a courier charge onto our products in future". The e-grocery operators' free delivery is made possible by discounts received from bulk purchases. The other e-grocery retailers charge a percentage for deliveries based on distance and time of delivery (peak or off-peak): "We charge a certain delivery fee which, at the moment, varies based on the time of the day". The other majority of grocery e-retailers charge a percentage based on the total groceries purchased. The example of percentage charged is: " $12 \%$ for groceries purchases of R700 to R15, and R60 for purchases in the scale of R3000". An attended delivery method is popular for all eight e-grocery operators. However, one e-grocery operator offers a pick-up at their nearest kiosk for unavailable customers whilst the others allow customers to recommend their preferred place, especially corporate clients: "If someone is not present first time, we return for the

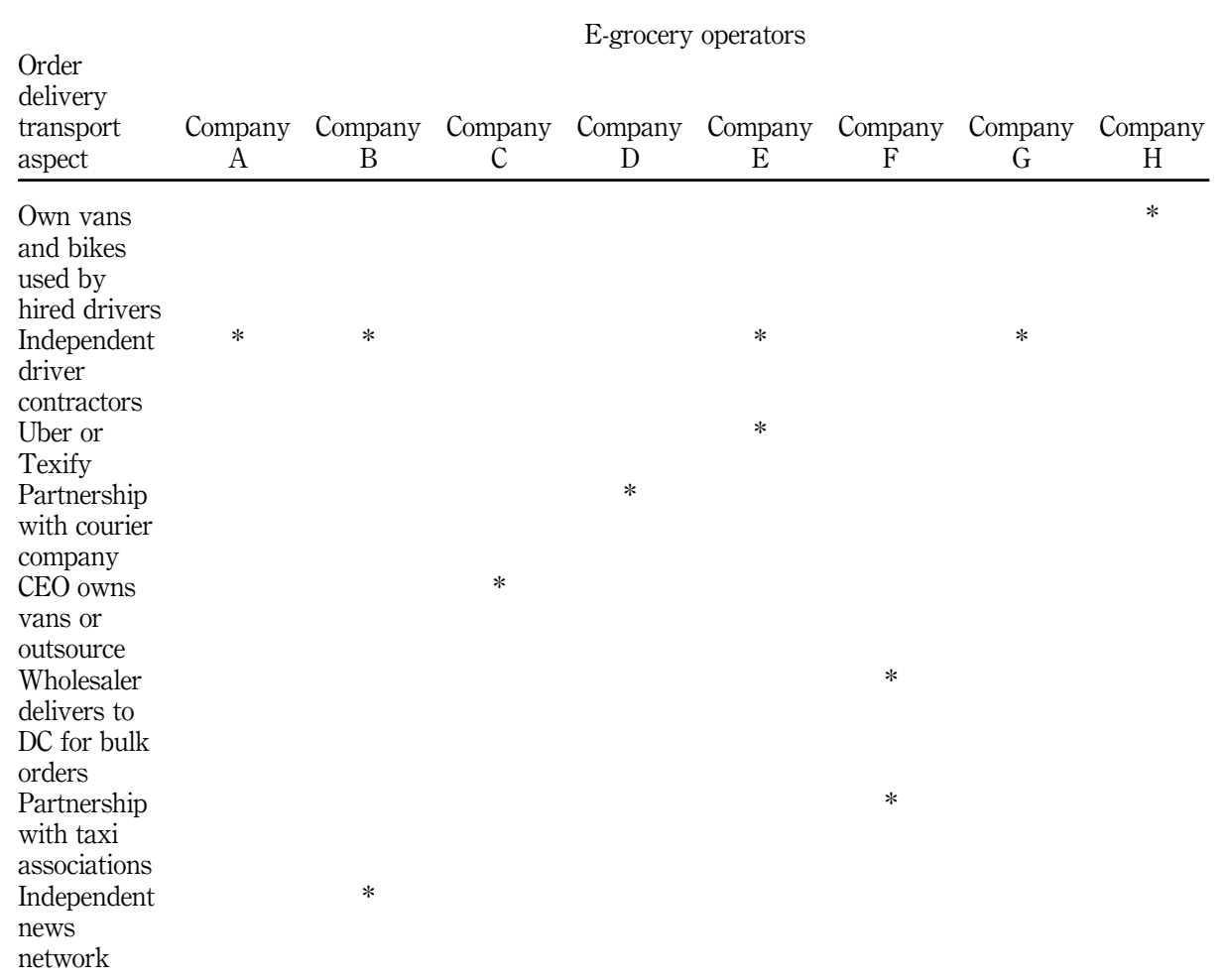

Table III. Order delivery transportation 
second time and, if unavailable, the customer picks up at the nearest kiosk". Other e-grocer retailers offer customers an option for a preferred delivery place within a radius: "The person who lives alone and with no helper or someone to pick-up the groceries tells us where to deliver or we deliver at the time when s/he arrives from work". In urban areas, a 1-h delivery time slot is in use and the delivery times are aligned to competitors' store operating times in which they pick groceries:

We use the operating times of the store; the store opens at $8 \mathrm{am}$ and closes at $8 \mathrm{pm}$. We are able to deliver within an hour. About $60 \%$ of our customers are actually within a $2 \mathrm{~km}$ radius of that store.

A one-time password system is used for security and ensuring delivery of correct orders. Two of the e-grocery operators use a code system sent to customers' mobile phones: "At delivery, a customer gives the driver a one-time passcode. That code then tells the driver what must be delivered". Whilst urban e-grocery operators offer daily deliveries, one of the township operators only delivers three days a week in an effort to aggregate demand necessary for free deliveries. The other township e-grocery operator offers a range of $24-48 \mathrm{~h}$.

\section{Discussion}

This study aimed to explore how small andmedium e-grocery businesses use innovations to bridge the supply chain challenge of limited resources and under-developed logistics infrastructure. The conceptual framework depicted in Figure 4 brings together the major findings of mobile application supported urban-township e-grocery retail (1), associated e-grocery distribution models (2) and logistics processes (3) discussed in the previous section. It portrays a holistic canvass that provides insight into factors fuelling small

Figure 4.

Mobile application configured framework for urban-township e-grocery distribution models

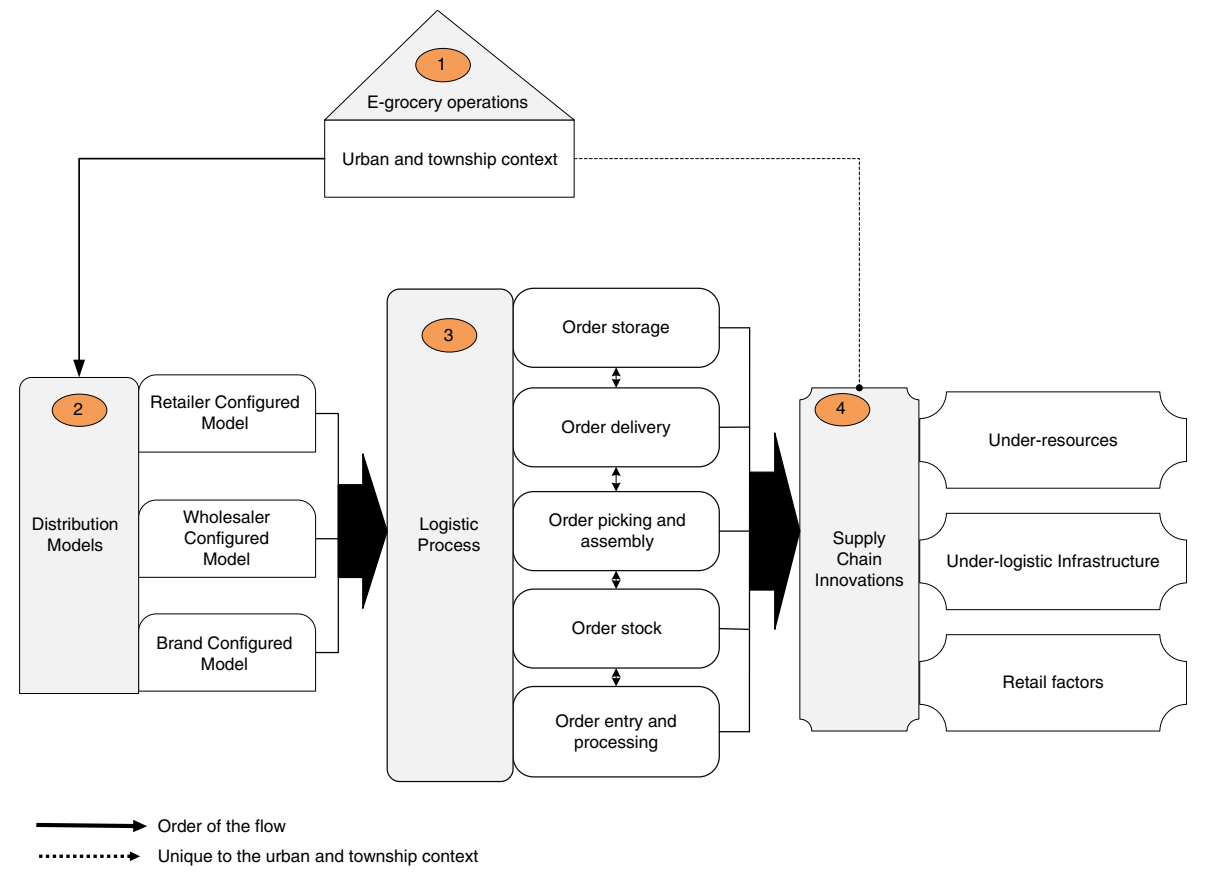


e-grocery retail resurgence which is considered a major barrier to entry (Ishfaq et al., 2016; Aspray et al., 2013). The supply chain innovations (4) are divided into three: for addressing under resources, under-logistics infrastructure, and those that fuel retail practices as discussed in depth in the sub-sequent sections.

\section{Supply chain innovations for addressing resourcing issues}

The study revealed a number of supply chain innovation for addressing resourcing issues, which are all integrated through the use of mobile applications across the different parts of the logistics process from order stock, order picking, order entry, order delivery, to order stock. At a basic fulfilment level, small e-grocery players can make use of competitors' assets to stock and pick e-groceries, activities which are coordinated through the use of mobile applications. This involves the use competitors' grocery assets, such as stock and infrastructure (stores), to advance access into the e-grocery business industry. Through this strategy, small e-grocers eliminate physical infrastructure (such as stores/DCs), inventory levels and its associated management needs (packing, replenishment and ordering), storage and its maintenance needs (cold storage, security, etc.). Put simply, their distribution strategy allows them to sweat their competitors' grocery stores assets and wholesales. Unlike traditional grocery retailers, this strategy allows them to push any retailer brand as requested by customers and thus they have no loyalty to any grocery retailer brand. They are able to offer customers the flexibility to shop from the grocery retailer of choice.

Our findings reveal profit-sharing models with big retailers based on sales percentages. E-grocery revenue model innovation is observed from the partnership between small grocery e-retailers and big grocery retailers, where big grocery retailers offer small e-grocers 5-10 per cent profit share on the basis of sales generated. In this regard, the mobile app serves as a data warehouse that aggregate sales and the necessary profit share between small e-grocery player and the participating grocery retailer. Moreover, the mobile application provides the base for real-time Big Data analytics regarding the consumption patterns and product demand variations of urban vs township and rural customers, information which is necessary to strengthen the e-grocery fulfilment process. Other offline grocery retailers and shopping centres can leverage on the model to increase store and mall sales and reduce waste of fresh produce and other chilled products. Such a strategy is more important in an environment of high fresh and chilled products waste and provides offline grocery retailers the capacity to intervene on food waste and react to uncertain competition.

For order entry, the small e-grocery players use digital platforms such as mobile application to aggregate demand from the downstream chain for economies of scale in the upstream chain. Their mobile application displays a catalogue of groceries, aggregates demand and facilitates communication between personal shoppers, drivers and the management towards achieving seamless retail. These findings extend the literature on the role of mobile applications in supporting supply chains and customer applications (Mishra et al., 2015; Pan et al., 2013). The apps transcend e-grocery barriers and enables small businesses with limited resources to leverage e-grocery market opportunities that are unimaginable in townships and rural areas.

To facilitate greater penetration into the market, the small e-grocery players forged a partnership with townships spazas as holders of stock and mini-DCs. The partnership and activities across the township spazas and household channel members are reinforced by the mobile application, with the interface designed specifically to easily facilitate the roles played by each partner. The partnership with household owners in townships and rural areas offers insight into a strategic extension of downstream chain to include household owners in between retailers and customers. The innovative e-grocer distribution strategy helps small e-grocers to avert the high cost of DCs whilst offering financial benefits in townships. 
Lastly, an interesting brand distribution model offers a direct route of groceries and other products to market, especially to the base of the pyramid. The approach serves as an alternative strategy in which brand owners can gain control over retailers, gather relevant data and interact better with their customers. Most importantly, it opens up a direct route to market for start-ups, FMCGs and small farmers subject to consignment conditions imposed by retailers. Furthermore, the brand distribution model amplifies the ubiquitous role of mobile applications in reaching out to the base of the pyramid, especially those that are mainly isolated from the digital revolutions.

\section{Innovations for under-developed logistics infrastructure}

The findings of this study reveal three innovations used to address under-developed logistics infrastructure. First, the use of GPS coordinates at point of order to capture accurate locations in unstructured townships which is later used for delivery of groceries. The strategy of capturing delivery location coordinates through mobile applications during order processing offers an innovative demand aggregation strategy that simultaneously address issues of unstructured roads and unstructured street numbers necessary for delivery of e-groceries.

Second, a partnership with distributors of products with high daily demand for deliveries, e.g., newspaper and passenger transport during off-peak hours. The joint-distribution of products with high daily demand and high penetration to the geographical market paves the way for better utilisation of truck space and cost reduction associated with delivery of products. Other businesses with high daily demand in urban, city and township areas such as bakeries might find the emerging distribution patterns as a "light bulb" moment for cost reduction and maximum utilisation of truck space. Most importantly, the partnership lights a bulb to a new wave of live traffic monitoring innovations that can help facilitate and coordinate the flow of goods across the supply chain.

Third, the deployment of women and unemployed youth for order entry is specifically used to address the lack of ICT infrastructure, expensive data and the existence of digitally challenged market groups. The mobile applications of the foot agents are loaded with internet data and they capture the orders on behalf of the digitally challenged groups. In particular, it reveals a pull strategy that gives small e-grocery players a bargaining position in the upstream chain and a base for establishing relationships with brands manufacturers. The judicial mix of socio-economic issues with the digital advantages of mobile applications serves as evidence of how township and rural e-grocery players develop and implement innovative business models that seek to uplift the well-being of socially disadvantaged and to redress social problems of inequality and marginalised groups.

\section{Factors fuelling small e-grocery retail in South Africa}

There are two identified factors that can better explain the resurgence of small e-grocery retailers in townships and rural areas. On the one hand, the existence of technologically challenged informal and formal traders such as stockfela societies, spaza shops, crèches, social grants holders, funeral paler and churches reveals an untapped market that exists in townships and rural areas. Parallel to the digitally challenged groups is the absence of big grocery retailers in rural and townships areas which equally opened a market for small e-grocery players. At best, the target of townships and rural areas reveal the process in which small e-grocery retailers with fewer resources and operating in under-developed logistical infrastructure disrupt the monopolised grocery market in South Africa through the use of mobile applications.

On the other hand, the involvement of students, women and unemployed youth as independent drivers and shoppers reveals a unique context where unemployment, spatial inequality and under-developed infrastructure acts as a stimulus that creates fertile grounds 
necessary to drive new mobile application innovation to market and fuels the momentum of small e-grocers. The latter involvement supports the premises of digital studies and information systems in advancing the role of innovation for social inclusion and towards addressing economic challenges such as employment (Reinecke and Ansari, 2016; Riaz and Qureshi, 2017).

\section{Conclusion}

This study presents supply chain innovations used to address under-resource and underdeveloped logistics infrastructure in urban-township and rural e-grocery distribution context. Most importantly, it reveals how mobile applications have converged to nourish the existence of small business and e-grocery supply chain whilst addressing some of the social and economic challenges. Our findings reveal how mobile applications in the context of urban, township and rural areas, serve as the rite of passage through which the foundations of e-grocery operations can be realised. The findings, therefore, have implications on the way e-grocery distribution models develop in different contexts and, possibly, how it can develop in other economies such as the BRICS nations with similar contextual patterns.

We introduced three mobile application innovation models; the mobile application retailer configured model, the mobile application wholesale configured model and the mobile application brand/FMCG configured model. The models are weaved with a set of complimentary innovative revenue and business models. The study also identified three categories of innovations that may help e-grocery retailers flourish in rural distribution and urban township areas: innovations to address resource issues, for developing infrastructure and innovations that help e-retailers in small e-grocery retail in developing economies. An interesting insight arising from the study is how the mobile digital platform enabled strategies that allowed emerging operators to exploit competitors' resources. In this sense, competitors' grocery stores serve as crucial conduit through which the relations between leading grocery retailers and small e-grocery retailers are articulated. Small grocery e-retailers are becoming complementary partners that extend major grocery retailers' channels to the online channel. Future research can explore other areas of business where these strategies are possible without ensuing conflicts between channel players.

It further offers a perspective of how technology is deployed in rapidly aggregating real-time demand and supply in developing economies with under-developed logistical infrastructure, whilst empowering informal and formal small and medium e-grocery retailers with limited resources in developing economies. Despite the limitations imposed by townships and rural areas, such as expensive data, unstructured road systems, immature logistics infrastructure and under-developed IT infrastructure, small e-grocers have innovatively devised means of deploying foot agents to aggregate demand on their mobile applications which gives them a strong bargaining position in the upstream chain. The innovative strategy drew interest of malls, competitors and FMCG companies. Future studies can draw contextual effects such as digital illiteracy, unemployment and innovation as possible dependent variables for explaining innovation resurgence and/or adoption drivers and the connection between urban, township and rural supply chains.

In practice, the mobile application configured e-retail model can be easily replicated in both the developed and developing world and the mobile application wholesale and brand models can be replicated in economies with high unemployment and digitally challenged communities for micro-jobs and market penetration. The conditions that underpin the three models offer future research an opportunity to explore potential transferability to other geographical context and product offerings. The involvement of township household owners, and spaza shops in the last mile offers ways in which most redundant buildings can be utilised to e-supply chain. Policy makers can build on the approach for any redundant buildings across the country. 
Whilst the study's findings paint a canvass of alternative e-grocery operations, it is acknowledged, however, that the small sample size of eight e-grocery players and its specific focus on small businesses in South Africa may not always be transferable to other service contexts and geographies. This calls for extension of this study to other geographies and retailers. Nevertheless, such distribution insight emphasises the importance of contextual relevance of township to rural e-grocery operations vis-à-vis urban e-grocery perspectives. Policy makers can use the insight to model necessary support packages that might fuel SMEs' growth, innovation and inclusion for the benefits of the economy at large.

\section{References}

Agatz, N., Campbell, A., Fleischmann, M. and Savelsbergh, M. (2011), "Time slot management in attended home delivery", Transportation Science, Vol. 45 No. 3, pp. 435-449.

Agwa-Ejon, J. and Mbohwa, C. (2015), "Financial challengesfaced by SMMES in Gauteng South Africa”, International Association for Management of Technology, IAMOT 2015 Conference Proceedings, pp. 520-534.

Alalwan, A.A., Dwivedi, Y.K., Rana, N.P. and Williams, M.D. (2016), "Consumer adoption of mobile banking in Jordan: examining the role of usefulness, ease of use, perceived risk and self-efficiency", Journal of Enterprise Information Management, Vol. 29 No. 1, pp. 118-139.

Alexander, P., Ceruti, C., Motseke, K., Phadi, M. and Wale, K. (2013), Class in Soweto, University of Kwa-Zulu Natal Press, Pietermaritzburg.

Asdemir, K., Jacob, V.S. and Krishnan, R. (2009), "Dynamic pricing of multiple home delivery options", European Journal of Operational Research, Vol. 196 No. 1, pp. 246-257.

Aspray, W., Royer, G. and Ocepek, M.G. (2013), “Anatomy of a dot-com failure: the case of online Grocer Webvan", in Aspray, W., Royer, G. and Ocepek, M.G. (Eds), Food in the Internet Age, Springer, Boston, MA, pp. 25-35.

Babbie, E. (2013), The Practice of Social Research, 14th ed., Cengage Learning, Belmont, CA.

Baptista, I. (2018), "Electricity services always in the making: Informality and the work of Infrastructure maintenance and repair in an African city", Urban Studies, Vol. 56 No. 3, pp. 510-525.

Bharucha, J. (2017), "Issues in the home delivery model in India", International Journal of Supply Chain Management, Vol. 6 No. 3, pp. 145-151.

Bisseker, C. (2015), "How load sheddinghurts the economy", Rand Daily Mail, 11 February, available at: www.businesslive.co.za/archive/2015-02-11-how-load-shedding-hurts-the-economy/ (accessed 2 May 2018).

Blanco, E.E. and Fransoo, J.C. (2013), "Reaching 50 million nanostores: retail distribution in emerging megacities", BETA publicatie, working papers, Vol. 404, Eindhoven, pp. 1-11, available at: https:/pure.tue.nl/ws/portalfiles/portal/3458387/731270145741620.pdf

Braun, V. and Clarke, V. (2012), "Thematic analysis", in Cooper, H., Camic, P.M., Long, D.L., Panther, A.T., Rindskopf, D. and Sher, K.J. (Eds), APA Handbook of Research Methods in Psychology: Research Designs: Quantitative, Qualitative, Neuropsychological, and Biological, Vol. 2, The American Psychological Association, Washington, DC, pp. 57-71.

Cagliano, A.C., DeMarco, A. and Rafele, C. (2017), "E-grocery supply chain management enabled by mobile tools", Business Process Management Journal, Vol. 23 No. 1, pp. 47-70.

Cagliano, A.C., DeMarco, A., Rafele, C., Bragagnini, A. and Gobbato, L. (2015), "Analysing the diffusion of a mobile service supporting the e-grocery supply chain”, Business Process Management Journal, Vol. 21 No. 4, pp. 928-963.

Calandro, E., Gillwald, A. and Rademan, B. (2014), "SA Broadbandquality drops but prices remain high", Research ICT Africa Policy Brief No. 6, available at: www.researchictafrica.net/ publications/Research_ICT_Africa_Policy_Briefs/RIA_Policy_Brief_August_2014_No_6_ Broadband.pdf (accessed 17 March 2019). 
Cant, M.C. (2017), "The availability of infrastructure in townships: is there hope for Township businesses?", International Review of Management and Marketing, Vol. 7 No. 4, pp. 108-115.

Clark, P.V. and Creswell, J. (2015), Understanding Research: A Consumer's Guide, 2nd ed., Pearson Higher Education, Upper Saddle River, NJ.

Durand, B. and Gonzalez-Feliu, J. (2012), "Urban logistics and E-grocery: have proximity delivery services a positive impact on shopping?", Procedia-Social and Behavioural Sciences, Vol. 39, pp. 510-520.

Eisenhardt, K.M. (1989), "Building theories from case study research”, The Academy of Management Review, Vol. 14 No. 4, pp. 532-550.

Eng, T.Y. (2006), "Mobile supply chain management: challenges for implementation", Technovation, Vol. 26, pp. 682-686, available at: http://citeseerx.ist.psu.edu/viewdoc/download?doi=10.1.1.549.2 407\&rep=rep1\&type $=$ pdf

England, A. (2015), "Power crisis knocks South African economy", Financial Times, 25 February, available at: www.ft.com/content/e853a048-bce7-11e4-9902-00144feab7de (accessed 2 May 2015).

Foster, V. and Briceno-Garmendia, C. (2010), "Africa's infrastructure: a time for transformation", in Foster, V. and Briceno-Garmendia, C. (Eds), The International Bank for Reconstruction and Development, The World Bank, Washington, DC, pp. 1-27, available at: https://siteresources. worldbank.org/INTAFRICA/Resources/aicd_overview_english_no-embargo.pdf (accessed 10 April 2018).

Gevaers, R., Van de Voorde, E. and Vanelslander, T. (2011), "Characteristics and typology of last-mile logistics from an innovation perspective in urban context", in Macharis, C. and Melo, S. (Eds), City Distribution and Urban Freight Transport: Multiple Perspectives, Edward Elgar, Cheltenham, pp. 56-71.

Goethals, F., Leclercq-Vandelannoitte, A. and Tütüncü, Y. (2012), "French consumers' perceptions of the unattended delivery model for e-grocery retailing", Journal of Retailing and Consumer Services, Vol. 19 No. 1, pp. 133-139.

Hosu, Y.S., Nakin, M.D.V. and Cishe, E.N. (2018), "River catchment dynamics and access to clean water in rural South Africa", African Population Studies, Vol. 32 No. 1, pp. 3917-3928.

Hubner, A., Kuhn, H. and Wollenburg, J. (2016), "Last mile fulfilment and distribution in omni-channel grocery retailing: a strategic planning framework", International Journal of Retail and Distribution Management, Vol. 44 No. 3, pp. 228-247.

Hughes, T.P. (2012), "The evolution of large technological systems", in Bjiker, W.E., Hughes, T.P. and Pinch, T.J. (Eds), The Social Construction of Technological Systems: New Directions in The Sociology and History of Technology, Anniversary ed., MIT Press, Cambridge, MA, pp. 4-76.

Ishfaq, R., Defee, C.C., Gibson, B.J. and Uzma, R. (2016), "Realignment of the physical distribution process in omni-channel fulfilment", International Journal of Physical Distribution and Logistics Management, Vol. 46 Nos 6/7, pp. 543-561.

ITU (2014), Measuring the Information Society Report 2014, International Telecommunication Union, Geneva, available at: www.itu.int/en/ITU-D/Statistics/Documents/publications/mis2014/MIS20 14_without_Annex_4.pdf (accessed 15 April 2019).

Khairunnisa, K., Ayob, J., Mohd, H.A., Wahab, M., Erdi, A.M., Izwan, A.M. and Ayob, A. (2009), "The application of wireless food ordering system”, MASAUM Journal of Computing, Vol. 1 No. 2, pp. 178-184.

Larke, R., Kilgour, M. and O'Connor, H. (2018), "Build touchpoints and they will come: transitioning to omni-channel retailing", International Journal of Physical Distribution \& Logistics Management, Vol. 48 No. 4, pp. 465-483.

Lawrence, J. and Tar, U. (2010), "Barriers to ecommerce in developing countries", Information, Society and Justice, Vol. 3 No. 1, pp. 23-35.

Lee, E. and Han, S. (2015), "Determinants of adoption of mobile health services", Online Information Review, Vol. 39 No. 4, pp. 556-573. 
Li, Y., Sun, Y., Zhang, Y. and Hu, X. (2018), "Online grocery retailing for fresh products with order cancellation and refund options", Journal of Supply Chain and Operations Management, Vol. 16 No. 1, pp. 1-16.

Lim, S.F.W.T., Xin, J. and Srai, J.S. (2018), "Consumer-driven e-Commerce: a literature review, design, framework, and research agenda on last-mile logistics models", International Journal of Physical Distribution and Logistics Management, Vol. 48 No. 3, pp. 308-332.

Liu, F., Zhoa, X., Chau, P.Y.K. and Tang, Q. (2015), "Roles of perceived value and individual differences in the acceptance of mobile coupon applications", Internet Research, Vol. 25 No. 3, pp. 471-495.

Lu, L. and Reardon, T. (2018), "An economic model of the evolution of food retail and supply chains from traditional shops to supermarkets to e-commerce", American Journal of Agricultural Economics, Vol. 100 No. 5, pp. 1-16, available at: https://academic.oup.com/ajae/article-abstract/ 100/5/1320/5077447

Makhubu, A. (2016), "A democratic city? The impact of transport networks on social cohesion", International Planning History Society Proceedings, 17th IPHS Conference, History-UrbanismResilience, TU Delft, Vol. 3, 17-21 July, pp. 223-234.

Marchet, G., Melacini, M., Perotti, S., Rasini, M. and Tappia, E. (2018), "Business logistics models in omni-channel: a classification framework and empirical analysis", International Journal of Physical Distribution \& Logistics Management, Vol. 48 No. 4, pp. 439-464.

Mishra, B.K., Choudhary, B.S. and Bakshi, T. (2015), "Touch based digital ordering system on android using GSM and bluetooth for restaurants", Annual IEEE India Conference (INDICON), New Delhi, 17-20 December.

Mkansi, M., Qi, B. and Green, G. (2011), "A literature review on management of e-retailers supply and distribution network: study ofthe UK grocery sector", UK Academy for Information Systems Conference Proceedings in Oxford, Oxford, 4 November.

Mkansi, M., Eresia-Eke, C. and Emmanuel-Ebikake, O. (2018), "E-grocery challenges and remedies: global market leaders' perspective”, Cogent Business \& Management, Vol. 5 No. 1459338, pp. 1-28.

Morganti, E., Dablanc, L. and Fortin, F. (2014), "Final deliveries for online shopping: the deployment of pickup point networks in urban and suburban areas", Research in Transportation Business and Management, Vol. 11, pp. 23-31, available at: https://hal.archives-ouvertes.fr/hal-01067223/file/20 14_morganti_ResearchTransportationBusinessManagement.pdf

Mourtzis, D., Doukas, M. and Vandera, C. (2016), "Smart mobile apps for supporting product design and decision-making in the era of mass communication", International Journal of Computer Integrated Manufacturing, Vol. 30 No. 7, pp. 690-707.

Murphy, A.J. (2007), "Grounding the virtual: the material effects of electronic grocery shopping", Geoforum, Vol. 38 No. 5, pp. 941-953.

MySuperSpar (2018), "Monument park SuperSpar home delivery service", available at: http://mpsuperspar. co.za/DELIVERIES/ (accessed 7 October 2018).

Nguyen, D.H., de Leeuw, S. and Dullaert, W.E. (2018), "Consumer behaviour and order fulfilment in online retailing: a systematic review", International Journal of Management Reviews, Vol. 20 No. 2, pp. 255-276.

Ntloedibe, M. and Geller, L. (2017), "South Africa retailfood industry", Global Agricultural Information Network Report, Pretoria.

Oduwole, O.A. (2018), "The significance of innovative entrepreneurship policy formulation in achieving developmental goals in emerging economies: a case of South Africa informal economy", International Journal of Research in Business, Economics, and Management, Vol. 2 No. 5, pp. 142-156.

Osterle, I., Aditjandra, P.T., Vaghi, C., Grea, G. and Zunder, T.H. (2015), "The role of a structured stakeholder consultation process within the establishment of a sustainable urban supply chain", Supply Chain Management Journal: An International Journal, Vol. 20 No. 3, pp. 284-299.

Pan, S., Giannikas, V., Han, Y., Grover-Silva, E. and Qiao, B. (2017), "Using customer-related data to enhance e-grocery home delivery", Industrial Management and Data Systems, Vol. 117 No. 9, pp. 1917-1933. 
Pan, Y., Nam, T., Ogara, S. and Lee, S. (2013), "Adoption model of mobile enabled systems in supply chain”, Industrial Management \& Data Systems, Vol. 113 No. 2, pp. 171-189.

Philip, K. (2010), "Inequality and economic marginalisation: how the structure of the economy impacts on opportunities on the margins", Law, Democracy and Development, Vol. Vo. 14 No. 2010, pp. 1-28.

Pick n Pay (2018), “Annual integrated report”, Pick n Pay, Cape Town, available at: www.picknpayinvestor. co.za/downloads/annual-report/2018/picknpay-ir-2018.pdf (accessed 7 October 2018).

Ploos Van Amstel, W.P. (2015), "Working on livablecities through sustainable city logistics", Urban Technology Research Program, Amsterdam.

Polacco, A. and Backes, K. (2018), "The amazon go concept: implications, applications, and sustainability", Journal of Business and Management, Vol. 24 No. 1, pp. 79-92.

Polit, D.F. and Beck, C.T. (2012), Nursing Research: Generating and Assessing Evidence for Nursing Practice, 9th ed., Wolters Kluwer HealthlLippincott Williams \& Wilkins, Philadelphia, PA.

Reinecke, J. and Ansari, S. (2016), "Taming wicked problems: the role of framing in the construction of corporate social responsibility", Journal of Management Studies, Vol. 53 No. 3, pp. 299-329.

Reiner, G., Teller, C. and Kotzab, H. (2013), "Analyzing the efficient execution of in-store logistics processes in grocery retailing: the case of dairy products", Production and Operations Management, Vol. 22 No. 4, pp. 924-939.

Riaz, S. and Qureshi, I. (2017), "Emergence of a new institutional logic: shaping the institutionally complex field of community Radio in India", in Seidel, S.L. and Greve, H.R. (Eds), Emergence, Research in the Sociology of Organisations, Vol. 50, pp. 383-418.

Rossman, G.B. and Rallis, S.F. (2011), Learning in the Field: An Introduction to Qualitative Research, 3rd ed., Sage, Thousand Oaks, CA.

Rushton, A., Croucher, P. and Barker, P. (2014), The Handbook of Logistics and Distribution Management: Understanding the Supply Chain, 5th ed., KoganPage.

Saldana, J. (2015), The Coding Manual for Qualitative Researchers, 3rd ed., Sage, Thousand Oaks, CA.

Saleem, M., Khan, M.M., Ahmed, M.E., Shah, S.A.N. and Surti, S.R. (2018), "Online groceryshopping and consumer perception: a case of karachi market in Pakistan", Journal of Internet and e-Business studies, Vol. 2018, doi: 10.5171/2018.93124.

Schoeman, T. (2018), "The spatial influence of apartheid on the South African city", The Geography Teacher, Vol. 15 No. 1, pp. 29-32.

Shackleton, C.M., Blair, A., De Lacy, P., Kaoma, H., Mugwagwa, N., Dalu, M.T. and Walton, W. (2018), "How important is Green infrastructure in small and medium-sized towns? Lessons from South Africa", Landscape and Urban Planning Journal, Vol. 180, pp. 273-281, available at: www. sciencedirect.com/science/article/pii/S0169204616302730?via\%3Dihub

Shih, C.W. and Wang, C.H. (2016), "Integrating wireless sensor networks with statistical quality control to develop a cold chain system in food industries”, Computer Standards and Interfaces, Vol. 45, pp. 62-78, available at: www.sciencedirect.com/science/article/abs/pii/S0920548915001452

Thi, H., Tran, T. and Corner, J. (2016), "The impact of communication channels on mobile banking adoption", International Journal of Bank Marketing, Vol. 34 No. 1, pp. 78-109.

Thulo, L. (2015), "The state of SA's township entrepreneurship", available at: www.smesouthafrica.co. za/15427/The-state-of-SA's-township-entrepreneurship (accessed 1 January 2016).

Tu, C., He, M., Ren, Y. and Qin, Y. (2018), "Research onthe logistics embeddedness in rural town E-commerce", in Li, X. and Xu, X. (Eds), Proceedings of the Fifth International Forum on Decision Sciences, Springer, Singapore, pp. 241-254.

Waitz, M., Mild, A. and Fikar, C. (2018), "A decision support system for efficient last mile distribution of fresh fruits and vegetables as part of e-grocery operations", Proceedings of the 51st Hawaii International Conference System, pp. 1259-1267.

Walmart (2018), “Annual report”, Walmart, Bentonville, available at: https://s2.q4cdn.com/056532643/ files/doc_financials/2018/annual/WMT-2018_Annual-Report.pdf (accessed 23 November 2018). 
Weber, A.N. and Badenhorst-Weiss, J. (2018), "The last mile logistical challenges of an omni-channel grocery retailer: a South African perspective", Journal of Transport and Supply Chain Management, Vol. 12 No. 1, pp. 1-13.

WHL (2018a), Annual Financial Statements, Woolworths Holding Limited, Cape Town, available at: www.woolworthsholdings.co.za/wpcontent/uploads/2018/09/WHL_2018_Annual_Financial_ Statements.pdf (accessed 7 October 2018).

WHL (2018b), "Integrated annual report", Woolworths Holding Limited, Cape Town, available at: www.woolworthsholdings.co.za/wp-content/uploads/2018/09/WHL-2018-Integrated-Report.pdf (accessed 7 October 2018).

Yang, X., Strauss, A., Currie, C. and Eglese, R. (2014), "Choice-based demand management and vehicle routing in e-fulfillment", Transportation Science, Vol. 50 No. 2, pp. 473-488.

Yin, R.K. (2015), Qualitative Research from Start to Finish, 2nd ed., Guilford, New York, NY.

Zaide, A.N.H. (2012), "Barriers to e-commerce adoption in Egyptian SMEs", International Journal of Information Engineering and Electronic Business, Vol. 4 No. 3, pp. 9-18.

\section{Further reading}

Massmart (2018), Interim Results for the Period Ended July 2018, Massmart, Rivonia, available at: www.massmart.co.za/wpcontent/uploads/2018/08/Massmart_Interim_Results_1July2018-2.pdf (accessed 7 October 2018).

Shoprite Holdings (2018), "Integrated annual report", Shoprite, Brackenfell, available at: www. shopriteholdings.co.za/content/dam/MediaPortal/documents/shopriteholdings/integratedreport/2018/Shoprite_IR_2018E_Full.pdf (accessed 7 October 2018).

Spar (2018), Interim Results Presentation, Spar, Pinetown, available at: http://investor-relations.spar.co.za/ wp-content/uploads/2018/05/SPAR-interim-results-presentation-29-May-2018.pdf (accessed 7 October 2018).

The World Bank (2014), "Economics of South African townships- special focus on Diepsloot", available at: www.worldbank.org/en/country/southafrica/publication/the-economics-of-southafrican-townships-special-focus-on-diepsloot (accessed 5 February 2016).

\section{Appendix 1. Grocery retail in South Africa}

In South Africa, the grocery industry is predominantly polarised by the top five major grocery retailers, namely: Shoprite, Pick n Pay, Massmart Holdings, Spar Group and Woolworths (Ntloedibe and Geller, 2017). The five leading grocery retailers have footprints beyond the borders of South Africa with much of their presence evident in the Sub-Saharan Africa, known as the Southern African Development Community (SADC region). Within this top five, only three of the major grocery retailers (Woolworths, Pick n Pay and Spar) are currently offering the online option to a limited market, mostly to the suburban areas of Gauteng and the Western Cape Province (WHL, 2018a, b; Pick n Pay, 2018; Mysuperspar, 2018). Pick n Pay's online grocery platform offers a 1-h delivery time slot and uses dedicated picking warehouses to satisfy the demand in Gauteng and the Western Cape. The company uses both website and mobile application to process online orders (Pick n Pay, 2018). Woolworths uses a selection of stores and a dedicated "dark store" to fulfil online orders, known as a hybrid model (WHL, 2018b). Spar has a website for specials, and offers a limited online grocery delivery through mpsuperspar.co.za to certain suburbs of South Africa's capital city (Pretoria): Monument Park, and Monument Park extensions (Waterkloof Heights, Waterkloof Ridge, Sterrewag and Erasmusrand) Mysuperspar (2018).

More recently, however, a wave of emerging e-grocery operators with no offline presence appears to have changed the landscape of e-grocery retail in South Africa. There are 13 micro-e-grocery players: Spazapp, Grocerease, Y-shop, Buy Grocery Online, Zulzi, Vuleka, Smartsentials, Onecart, Sisonke Africa, StockUp, Washesha, Wumdrop and Zanel groceries, that are offering e-groceries to urban, township and rural markets. These small e-grocery players, just like many other small businesses, have very little support, if any, in terms of marketing, limited financial resources and DCs, no stores, immature logistics, bargaining powers for economies of scale and warehouses that are typically at the disposal of large e-grocery retailers. However, there is a mismatch when the top ten offline grocery retailers are compared to their online counterparts given that they operate in the same geographical 
locations. Similar to global market developments (cf. Mkansi et al., 2018), the South African e-grocery market is not dominated by the traditional top grocery retailers but rather by the new online grocery retailers. The challenges for these e-grocery retailers are considerable, especially considering the contextual differences (i.e. urban vs township and rural contexts), and the infrastructural muscle between big organisations and small businesses (i.e. stores, DC and logistics capabilities). Pick n Pay and Woolworths use hybrid distribution models (the use of retailers' own stores and DCs assets) (WHL, 2018a, b; Pick n Pay, 2018). Spar uses a piggyback distribution model which is picking from the existing chain of the stores (Mysuperspar, 2018).

\section{Appendix 2. Sampling}

The study received access to eight case studies from the 13-known pertaining to the emerging population of national urban to township e-grocery operators in South Africa. The number of case studies selected is in line with the recommendation of four to ten cases recommended by Eisenhardt (1989). Whilst the maximum number of the township grocery e-retailers' cases was desired, the efforts were hampered by limited accessibility to the 13 small e-grocery retailers. The fears led to one e-grocery CEO's withdrawal, which left eight case-study participants. In particular, CEOs of the township e-grocery operators were purposively selected as they are the master minds behind the distribution strategies and, in most cases, they are in charge of the entire operation as observed in the practice of many small and medium enterprises. Put simply, a purposive homogeneous sampling was used to select cases and participants on the basis of their e-grocery retail to townships and urban precinct, positions of the participant and technology innovation-based characteristics different from the traditional and big grocery retailers such as Woolworths, Pick n Pay, Spar and Shoprite Checkers. All case participants in this study, Spazapp (CEO), Grocerease (COO), Y-shop (CEO), Buy Grocery Online (CEO) (buygroceryonline.co.za), Zulzi (CEO), Vuleka (CEO), Smartsentials (CEO) and Sisonke Africa (CEO), gave consent for their names to be revealed as samples for awareness of their good practice and existence. However, in reporting of findings, pseudonyms are used to maintain their anonymity when it comes to details of the practices applied. Spazzapp has been operating for three years under the stewardship of two senior executives and a team of 15 employees. Smart essentials have been operating for two years under two senior managers, however, extra staff are recruited on an ad hoc basis to reflect demand. Grocerease is under the management of three permanent executives and relies on independent contractors to support different e-grocery logistics elements. It has been under operation for two years. Zulzi have two senior managers, and 50 permanent shoppers, and maintains a consistent relationship with $100 \mathrm{ad} \mathrm{hoc} \mathrm{independent} \mathrm{shoppers.} \mathrm{Y-Shop} \mathrm{is} \mathrm{one} \mathrm{year} \mathrm{old} \mathrm{and} \mathrm{operates} \mathrm{an}$ e-grocery service under the stewardship of three executives. Sisonke Africa have one CEO and eight employees, and Vuleka is under the management of two senior executives and two permanent employees. Both Sisonke Africa and Vuleka are two years old. Buy Grocery Online is under the management of one executive and have ten permanent employees. It has been delivering e-groceries for less than a year. They all represent contrast in terms of their geographical retail and e-grocery distribution models (Table AI).

\section{Interviews}

Semi-structured interviews were held with eight CEOs of the e-grocery operators. The underlying theme of the semi-structured interview was guided by the fundamental elements of logistics germane to e-grocery retail such as order storage (storage and facilities), order entry and processing (communication), order stock (inventory), order delivery (transportation) and order picking and assembly (unitisation and packaging) (Mkansi et al., 2018). The latter logistics elements are considered the central backbone underlying the key success and competitiveness of many industries (Rushton et al., 2014; Hubner et al., 2016). The geographical distance and busy schedule of the eight CEOs favoured a telephone interview strategy whilst a face-to-face interview was held with one of the CEOs who was freely available. The interviews were recorded, with the verbal consent of the participants, on the desktops' voice recorder system and lasted for the durations of 38 min (for two participants), 41 min (two participants), 33 min (two participants), and $1 \mathrm{~h} 15 \mathrm{~min}-1 \mathrm{~h} 25 \mathrm{~min}$ (two of the participants). An outline and purpose of the study was supplied to all participants prior to the interview. Interviews were transcribed and e-mailed to participants to confirm accurate recording and clarification of unclear recording where necessary. 


\section{IJPDLM}

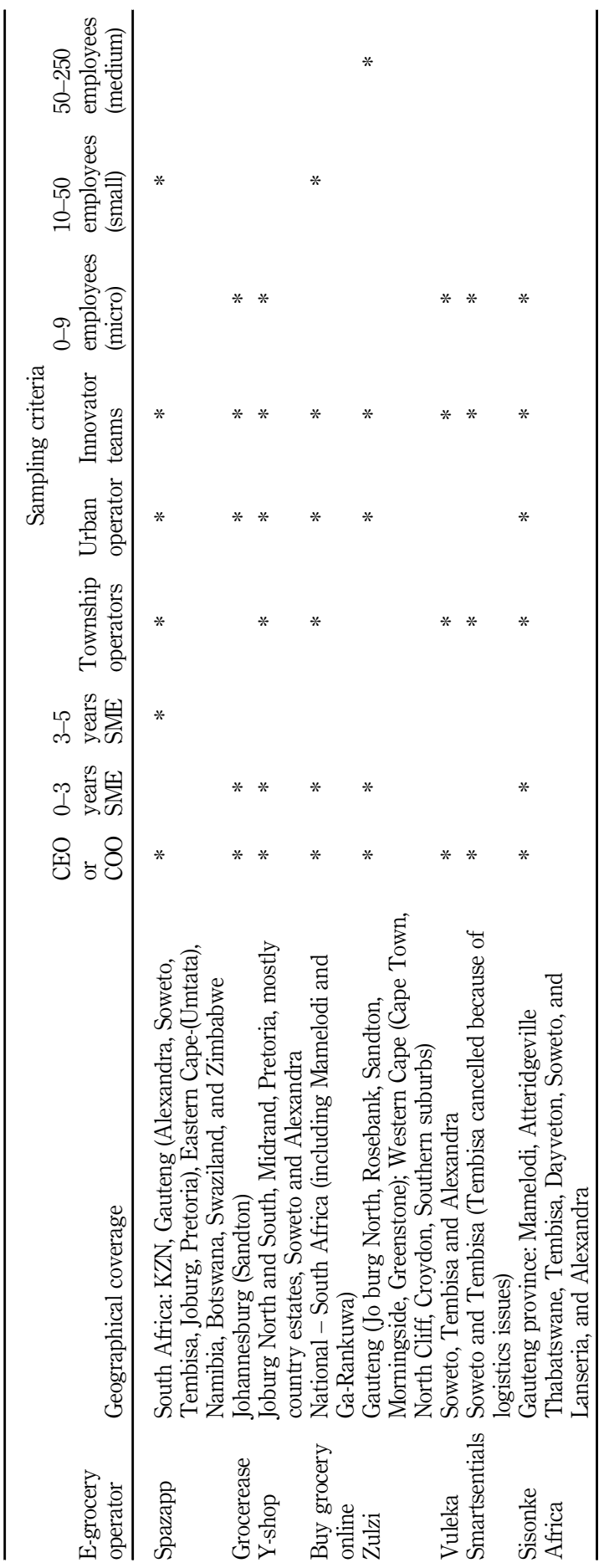

Table AI.

Sampling profile 


\section{Data analysis}

Data were analysed using Atlas Ti. The first step in Atlas Ti involves open coding where thoughts, ideas, meaning and concepts relevant to the study are identified within the unstructured data and classified into keywords or phrases (micro-codes) given by the participants. This particular approach is advised by Babbie (2013) who emphasises that open coding is used as a starting point and that failure to open up the transcripts compromises the analysis and communication that follows the research. The micro-codes are reapplied whenever a similar description is observed in other transcripts in an effort to reduce redundancy and maintain consistency in accordance with the guidance of Braun and Clarke (2012). All micro-codes were later linked into themes from the literature (Saldana, 2015) which, in this study, are the logistics elements germane to e-grocery retail and serve as a master code function for the study within Atlas Ti. The practice of linking micro-codes from primary data to literature themes (secondary data) is rooted in thematic analysis and extensively discussed by Braun and Clarke (2012). The trustworthiness and transferability of the study involves some of the approach outlined by previous scholars (Yin, 2015; Polit and Beck, 2012) of providing background description of the research context before the interview, outline of methodology to the participants and the preservation of transcripts. The transcripts were also shared with e-grocery operators after the interview session and are outlined in this paper. The audio records and transcripts of the eight e-grocery operators are some of the practice and evidence considered appropriate and relevant for convergence and support of the constructs discussed by Yin (2015) and Rossman and Rallis (2011).

\section{Appendix 3. Quotes from retailers}

This appendix contains the quotes from retailers that illustrate the concepts in the main text.

\section{Mobile application retailer configured model}

An interviewee on the mobile application retailer configured model:

We built a mobile App that is available on both the Play store and the Apple store and that seems to be the platform we are using to manage everything, and we sort it all in-house. It takes only three of us and at the moment the idea is to connect customers with their nearby retailers. We provide the service for customers to get their goods from Pick and Pay, Woollies, Dischem and every other retailer on-board. The stores front, effectively come through our App, and customers have a choice where they can place three orders from multiple stores at once. And we have personal shoppers that can shop on behalf of the customers, and then independent driver delivers to customers.

An interviewee on the relevance of informal partnership:

We do not have any formal partnerships right now, but we shop without the concern of this big supermarket. We do not see any need to involve them in our circle for now because it is just going to delay us to the market; it is going to be meeting after meeting and take 2 to 3 years to get sorted. There are lots of distribution points in Johannesburg, so we do not want any extra costs of distribution warehouses. We use existing retail points as our warehouses; that is how we have built our model. In townships, we use the township shopping malls such as Pick n Pay, Shoprite, and Woollies in Soweto. So all the big retailers are already there and that is where we go and buy for our customers I think the advantage for us is more on the consumable companies that advertise on our mobile application and want to partner with us. The biggest challenge for the consumable companies at the moment is that the retailers are actually making all the products that compete with them you know.

\section{Mobile application wholesale configured model}

An interviewee on the mobile application wholesale configured model:

We have an aggregation platform but we are currently developing version 2 so basically the app aggregates small orders from different spaza shops. Spaza shops are like kiosks in Nigeria. We call them spaza shops, tuck shops, a small mini convenience shop. So, we aggregate their purchases and then we create one bulk purchase. And with that bulk purchase we are able to negotiate discounts. 
If we negotiate, let s say $10 \%$ discount, we put 4 to 6 percent and give our customers a $4 \%$ discount on the goods that they currently ordered at a wholesale level.

B2B: Your business customers are businesses that use food ingredients, that is, groceries as inputs in their business so your bakeries use flour and sugar. Your shisanyama use maize meal, tin food and a whole bunch of things. You have amagwinya (translates to fat cakes), using flour, oil, and sugar daily. Others are fish and chips providers and kotha providers that use food as inputs. A very big customer are caterers who use fresh produce in their cooking for events and crèches that feed kids every day. We have churches and any business or institution. In Dayveton we have picked up undertakers, so he sells policies, but we put together a combo for him for R500. He used to give people R500 cash when they came to claim a policy, now they get R500 combos. There is a nice pack of food and that pack has gone as far as Newcastle... they buy $25 \mathrm{~kg}$, 50kg bags of flour in a 1 pallet.

B2C: You then have individuals and households who are buying for home consumption. Their buying quantities are not that high. You have your social grant receipts, whose spend maybe R300 to R400 on groceries, you have middle income households that will spend up to a R1000 on groceries, but they would typically buy at the middle of the month end. They will also buy sometimes whenever they have events at home, for example, a wedding at home, a birthday party, or there is something going on. So those are the two.

Economies of scale strategy: We have gone out and looked for products at the best prices possible. We go to a lot of mass discounters and independent wholesalers who are able to offer prices at up to $20 \%$ cheaper than your normal retails and so we buy products there. What that allows us to do is to add a certain markup to that price and that is the price at which we sell. And what happens is we get more and more scale and, effectively we are able to increase that margin to cover the cost of logistics and delivery. Fresh produce is very interesting; we buy it at the Tswhane market or the Joburg market. Every day the price is different and the guys that sell the fresh produce market can give you a discount on the spot. So, you might see a sign that say potatoes (10kg bag), it might be written there R38, but you go and tell the guy you want 20 bags and literally the guy can take R4 off right there. On Wednesdays the prices start to drop because they need to clear it out. And I mean if you are getting R4 off at something that started at R38 that is more than $10 \%$. So it's all about the volume, how much you buy.

\section{Mobile application brand/FMCG configured model}

Our business was always around creating a link between the informal and formal market and by that we knew that brands and FMCG companies wanted to get more, let s call it hands on or closer to that small market. We really focused on how to create that bridge between informal and formal markets. At its core, we approach FMCG brands, and look at how we can start almost cutting out a lot of that root to market so that there is a direct link between them and the spaza shop and we do that through technology. The type of technology in our world is mainly smart phone based and over the last year that has proved very resourceful in terms of having smart phone devices in South Africa but also across Africa.

Our relationships is with the brands and not with the buying stock. We are not wholesaler; we do not buy stock, make a markup and sell it. We are very much a marketing tool and for brands. We believe that brands should be the one paying for the bill and not shops that already have our markets. The cheaper we can make it for our spaza shops, the better for us and so we enable that relationship by creating a better route to market. Brands pay up because we have a much more direct route to those smaller stores. That is where the demand comes from and therefore, we get our payment through them rather than through the stores. The informal market and that branding awareness is what the brands pay us to drive.

\section{Logistics process management in urban-township e-grocery distribution Order entry and processing (communication)}

We have developed a mobile application through which the groceries can be ordered. Now, instead of requiring people in townships to download our applications on the phones, we find young people 
from the township whom we train and upskill. We deploy them into the township to go and act as agents. Basically, they find customers, tell them about our business and learn about the business and effectively sell products to them. When the customer places their orders, the orders are captured onto the app. We see all of the orders that come in the back office and we can then handle all the fulfilment. So, then we aggregate the orders, go out and buy and we deliver directly to the customer for no additional charge A challenge is that people in the township are struggling with data and also understanding how to use internet platform. But now, how we go about it is that mostly we meet with people at market and others prefer talking to us on WhatsApp. And then they prefer us making the orders for them and not them using the platform.

\section{Order stock (inventory)}

So right now, we do ambient, we do fresh produce that can be stored in ambient. So, potatoes, onions and butternut. We do not do frozen or chilled, not at all. We do not partly because of our supply chain constraints because the moment you start transporting and supplying frozen food, for example, the quality requirements mean that you need to maintain the temperature across the value chain and it needs to be traceable.

\section{Order storage (storage)}

Formal guidance: I was talking about the standard as an example, so with the frozen stuff like ice cream we have to keep it at zero degrees. We have some bags used by our shoppers that are kept in the stores' deep freezers. Whenever there is an order that requires i.e. ice cream, the shoppers put the ice cream into those bags. Woollies have specifications in terms of how they want their frozen product to be delivered.

Kiosk cross docking: We do not store or hold stock for a long period of time. We pick it up and drop it to customers. Storage as a whole is still a no-no. Right now, we break bulk either in the bakkie or at some of our locations; we call them kiosk. We are either breaking it because it needs to go in separate directions or because the quantities they need to flow out are just too small to go in such a big vehicle. So, it needs to go smaller with things like bicycle.

Partners with spaza shop customers: We look for big spaza shops and, at the moment, we have one guy that buys R32000 worth of stock every week. We approach a person like that and say listen, we will deliver the stock to you and then we will even give you buffer stock for you to help us supply to people around you. We sort of put them in a business where they become like a mini DC for us, but also help us to save costs. Instead of going daily to the same person that orders low volumes, they can actually get the stock from a micro DC. He uses the app to order and sends that order to us. We get it electronically and he even makes a deposit into the account. He is pushing more volumes and we are saving. So somehow, we need to give him a discount that also makes sense in terms of absorbing some of his running costs.

Time frame strategy: We work with time frame; we know when to deliver to customer $\mathrm{x}$. We ask the customer when to deliver i.e. if the customer wants his/her order to be delivered at $3 \mathrm{pm}$, we usually buy the groceries in the supermarkets at the shopping mall that is nearest to his/her house nearest to the desired time. That is how we make sure that the ice cream gets there while it is still intact. Once we purchase we get there as soon as possible whilst the goods are still intact.

Partnership with households: We work with independent distributors so instead of having our own network of stores and trucks we use other people's warehousing and distribute stock through that model. In Durban central we put smaller hubs into different townships areas and that creates the network. We create better hedge market there and so stock comes to our store and we deliver to our smaller micro distributors in the various townships who then deliver within a 20k radius. We break it down into smaller loads that go into our micro distributors that are based within the townships and they depend on size but they mostly double garage size. They are actually double garages because of security access. It is a person that we found that 
manages the warehouse and his community around him. So, it just depends on how best to approach each township because you cannot really look across the market generically. Eastern Cape is very different to KwaZulu-Natal (KZN) which is extraordinarily different to Gauteng and you got to take all of those into consideration.

\section{Order picking and assembly (unitisation and packaging)}

The executive opined that: It depends on the number of orders; sometimes we have lots of orders where we have to outsource and actually recruit people to help us do the shopping and delivery and sometimes we just do it ourselves internally. We manage, we work hard, we do it ourselves.

\section{Order delivery (transportation)}

When we have small deliveries. We use a smaller vehicle and a bigger vehicle for larger deliveries or quantities. In Gauteng, the big vehicle goes and gets everything in bulk and then the smaller deliveries take them around. Last year, and early this year, we used Getz, powered scooter, and tried different modes.

We have a partnership with a third-party courier company and they deliver throughout South Africa. They deliver to the townships, so our target market is from the higher upper class to middle class and even to your lower-class people that have to wake up at 5 o'clock in the morning and only come back at 8 o'clock at night. We try to make life easier for them.

We are using an Uber model on taxis. Taxis peak hours are 6 to 9am and off-peak from 10am to $12 \mathrm{pm}$. We spoke to a taxi association and offered to pay them a full load passenger price if they do 5 deliveries for us and they agreed. The taxi driver collects 5 orders for the value of R50, which is a full local taxi price. Yes, well, nobody will hijack taxi people.

In townships, street names do not exist. We use the coordinates and not the street address. What you have is House 4619 , Zone $\mathrm{C}$, but the location is right. The location is what we use to navigate and optimise i.e. if there is five dropped pins in this area we do all five with the same vehicle.

We try to deliver on Mondays, Wednesdays and Fridays. If a customer orders on Monday and Tuesday up to $3 \mathrm{pm}$, they receive orders on Wednesday and for orders made Wednesday a nd Thursday before 3pm, delivery is done on Friday. Orders received Friday after 3pm, Saturday or Sunday are delivered on Monday. That is how we have done it to give us a long period of time to aggregate.

\section{Corresponding author}

Marcia Mkansi can be contacted at: marcia.mkansi@gmail.com

For instructions on how to order reprints of this article, please visit our website: 